A Short History of Naval and Marine Engineering By Eng.-Capt. Edgar C. Smith. Pp. xix $+376+16$ plates. (Cambridge : At the University Press, 1938.) 18s. net.

A $\mathrm{S}$ the editor of Engineering points out in his A foreword, most of the material in this work has appeared in the pages of that journal, but its re-issue in book form is more than justified. The author, who is now president of the Newcomen Society, has traced the development of marine engineering from the early reciprocating engine to the turbine and diesel, and from the rectangular flue boiler working at less than $5 \mathrm{lb}$./in. ${ }^{2}$ to the forced circulation boiler of to-day. So much of the corresponding development in the field of naval architecture as is required to make a complete picture is also described.

While not in any way a text-book in the conventional sense, a perusal of this book should be as inspiring to the student as it should be attractive to the non-technical reader, to whom more especially the accounts of early voyages of steam vessels will appeal. As a work of reference, it will have lasting value; the index is excellent, and an extensive bibliography is scattered through the text.

In a chapter on the turbine, an intensely interesting light is thrown on the genius of Watt. The author tells us that in a letter full of calculations to Boulton in 1784, after hearing of the re-invention by Kempelen of what was in effect Hero's reaction turbine, Watt wrote with uncanny vision: "So that you see the whole success of the machine depends on the possibility of prodigous velocities . . . in short without god makes it possible for things to move 1000 feet $\mathrm{pr}^{\prime \prime}$ [i.e., per second] it can not do much harm".

A plea must be made to the author to apply in the next edition the correct epithet to ship-model testing tanks. That of Froude the elder may well have been experimental, but to-day, in an experiment tank, it is only the models which are experimental.

G. V. B.

\section{Elektrotechnische Berichte}

unter Mitwirkung des Verbandes Deutscher Elektrotechniker e.V., herausgegeben von Franz Moeller VDE, Berlin. Band 4, Heft 6, 15 Januar, 1938. 6 Bde. yearly. (Berlin: J. Springer.) 48 gold marks each.

$\mathrm{T}$ $\mathrm{HE}$ advent of a major abstracting journal is an event of considerable importance in the scientific world. The subject of this one is electrical engineering. Existing periodicals devoted to abstracting, or indexing, electrotechnical literature are thirteen in number. If we except the Deutches Rundfunkschriftum and the Wireless Engineer, which include a number of articles of less importance, hitherto no journal has included so many abstracts on electrical engineering as Science Abstracts B, and this contains only some three thousand five hundred in a year.

The new journal appears in fortnightly parts, forming six complete volumes annually, and comprising altogether a total of seven thousand abstracts, of which from four thousand to four thousand five hundred are taken from purely electrotechnical periodicals, while the remainder come from journals dealing with general science or cognate subjects, or represent notices of books. The length of the abstracts varies considerably, apparently being adjusted according to the values at which the articles are appraised.

The titles of the articles are quoted, as they should be, in the language of the original, and are also translated into German. The fact that the abstracts are in German is a drawback to English readers. But this difficulty is overcome to a large extent by classifying each abstract minutely by means of the decimal classification, several numbers being added to an abstract if the subject requires. This enables the abstracts of papers on any particular subject to be picked out with the greatest of ease, irrespective of language.

In spite of its high price, this new periodical is likely to become a standard abstracting journal in its subject.

\section{Solvents}

By Dr. Thos. H. Durrans. (Monographs on Applied Chemistry, under the Editorship of Dr. E. Howard Tripp, vol. 4.) Fourth Revised and Enlarged Edition. Pp. xvii +238. (London: Chapman and Hall, Ltd., 1938.) 15s. net.

THERE is a plethora of books to-day dealing 1 with one aspect or another of the use of organic solvents in industrial operations. Almost the earliest of these was that of Dr. Durrans ; its utility is made clear by the fact that a fourth edition is now required. The preface speaks of a complete revision and amplification and an attempt to make it of use to a somewhat wider industrial field.

In particular, progress has been made in the field of plasticizing solvents. The appendix giving the probable composition corresponding to the numerous trade names for solvents has been enlarged, also the useful table indicating the solubility of sundry resins and varnishes in the solvents.

The book retains its former general character and will be as heretofore indispensable to anyone who has to do with solvents: it is most thorough in every detail.

\section{Die Fermente und ihre Wirkungen}

Von Prof. Dr. Carl Oppenheimer. Supplement, Lief. 7 (Band 2, Specieller Teil, Haupt-Teil 16, 17). Pp. 943-1102. $10 \mathrm{fl}$. Supplement, Lief. 8 (Band 2, Specieller Teil, Haupt-Teil 17). Pp. 1103-1262. $10 \mathrm{fl}$. (Den Haag : Dr. W. Junk, 1937.)

THIS supplement progresses towards its completion which, at the time of writing Part 8, is put down as requiring another six months. The two parts now received deal with thrombase, the fibrin ferment of the blood, and begin the fourth main section entitled "Desmolases". The theories of the oxidation-reduction chain of reactions and the wellknown catalysts, including cellular fermentation, are described.

As these matters are in the forefront of interest at the present time, workers will appreciate having the literature summary brought up to date. The treatment follows familiar lines. 